\title{
Root Collar Excavation for Postinfection Control of Armillaria Root Disease of Grapevine
}

\author{
Kendra Baumgartner, Research Plant Pathologist, United States Department of Agriculture-Agricultural Research
} Service, Davis, CA 95616

\begin{abstract}
Baumgartner, K. 2004. Root collar excavation for postinfection control of Armillaria root disease of grapevine. Plant Dis. 88:1235-1240.

Root collar excavation for control of Armillaria root disease of grapevine was investigated in two California vineyards (vineyard K1 and vineyard N1) from 2002 to 2004. The hypothesis tested was that root collar excavation, when timed in early stages of root collar infection, may cause mycelial fans of the pathogen Armillaria mellea to recede from the root collar before severe disease results from vascular tissue decay. In vineyard N1, excavation significantly increased yield and cluster weight of symptomatic grapevines; symptomatic-excavated grapevines had the same high mean cluster weight as healthy grapevines, and there were no significant effects of excavation on yield or pruning weight of healthy grapevines. In vineyard K1, where excavated root collars frequently refilled with soil, excavation had no significant effects on yield or pruning weight of symptomatic grapevines, and significantly reduced pruning weight and shoot weight of healthy grapevines. Reexamination in March 2004 revealed that mycelial fans had receded from root collars of symptomatic-excavated grapevines, but remained on root collars of symptomaticnonexcavated grapevines. Root collar excavation appears to be a promising cultural approach for control of Armillaria root disease, as long as excavated root collars are kept clear of soil.
\end{abstract}

Additional keywords: Vitis vinifera

The causal organism of Armillaria root disease of grapevine (Vitis vinifera L.) in California is Armillaria mellea (Vahl:Fr.) P. Kumm., which also occurs on the roots of many common forest tree species, such as Quercus kelloggii Newb. and Pseudotsuga menziesii (Mirb.) Franco, in areas where vineyards are established $(2,3,7)$. When forest trees with Armillaria root disease are cut down, infected roots that remain below ground serve as a source of inoculum for grapevines planted on the site. Armillaria root disease of grapevines is an increasing problem in California as the clearing of forested hillsides for vineyard establishment continues.

Partial control of Armillaria root disease in orchards and vineyards can be achieved through preplant soil fumigation. Past research has shown that methyl bromide and carbon disulfide either kill or weaken A. mellea mycelium in buried wood seg-

Corresponding author: K. Baumgartner

E-mail: kbaumgartner@ucdavis.edu

Research was supported by the Viticulture Consortium and USDA-ARS.

Accepted for publication 21 June 2004.

Publication no. D-2004-0902-02R

This article is in the public domain and not copyrightable. It may be freely reprinted with customary crediting of the source. The American Phytopathological Society, 2004. ments, which predisposes the pathogen to attack by antagonistic soilborne fungi such as Trichoderma viride Pers.:Fr. $(9,10,12)$. However, soil fumigants typically do not reach all $A$. mellea-infected tree roots. Efforts to eradicate A. mellea from infected orchard trees and grapevines through fungicide or biocide application to the surrounding soil are unlikely to affect the fungus, because it grows beneath root bark. Research on sodium tetrathiocarbonate showed that postinfection applications to almond trees grown on Lovell peach rootstock were ineffective (1).

Results of previous studies have demonstrated the potential of a cultural approach, root collar excavation, for control of Armillaria root disease $(5,11)$. The technique involves permanent removal of soil from the base of the host's trunk to the depth at which main roots originate, in an effort to protect this important part of the root system from vascular tissue decay. Root collar excavation was shown to extend the productive life of Citrus spp. with Armillaria root disease in California $(5,11)$. On grapevine, root collar infection by A. mellea is a critical step in development of Armillaria root disease (4). Root collar infection by $A$. mellea involves the formation of a mycelial fan underneath the bark at the root collar, decomposition of the underlying cambium, and, eventually, decay of the secondary xylem. This girdles the trunk, preventing vascular tissue from functioning adequately. Foliar symptom develop- ment and rate of death is higher among hosts with root collar infections of $A$. mellea than among hosts with main root infections (18).

Spread of a mycelial fan to a previously uncolonized section of a root does not result in immediate vascular tissue decay in that section (16). Root collar excavation, when timed early in development of root collar infection, may cause a mycelial fan at the root collar to recede before it starts to decay underlying vascular tissue. Based on examination of entire root systems in a California vineyard, grapevines can tolerate a mycelial fan that covers the root collar for at least one growing season without showing severe aboveground symptoms of root disease (4).

The goal of this research was to evaluate root collar excavation for postinfection control of Armillaria root disease, which required a method of quantifying treatment efficacy. Data typically collected for root diseases, such as percent root infection and percent mortality of infected plants, are difficult to apply to Armillaria root disease. Mycelial fans grow beneath the bark of woody roots, making it difficult to quantify signs of $A$. mellea and extent of infection. Greenhouse experiments with A. mellea are complicated by its slow rate of colonization (on the order of months to years) and, hence, slow foliar symptom development on inoculated plants (19). Obtaining percent mortality data is a protracted exercise because A. mellea can take many years to kill an infected host $(14,15)$. Also, because inoculum (A. mellea-infected wood segments) cannot be accurately quantified, there is large variation among inoculated plants.

In the field, grapevines with obvious foliar symptoms of Armillaria root disease (dwarfed leaves, wilting, premature defoliation) frequently also have smaller shoots than healthy grapevines (13). Shoot diameter is used by vineyard field crews to make decisions regarding grape cluster removal (the thinner the shoot, the fewer clusters left on the shoot); therefore, we might expect that symptomatic grapevines with stunted shoots also have lower yield. If yield and growth of symptomatic grapevines are significantly lower than that of healthy grapevines, amelioration of these impacts could be used as measures of the efficacy of postinfection control of Armillaria root disease.

In this experiment, yield and growth measurements were compared between 
healthy and symptomatic grapevines, with and without excavated root collars, in the field in order to determine if these quantitative data are useful for assessing efficacy of postinfection treatment of Armillaria root disease. Specific objectives were to (i) examine the effects of root collar excavation on yield and growth of symptomatic grapevines and (ii) assess the impact of root collar excavation on healthy grapevines.

\section{MATERIALS AND METHODS}

Research was conducted in two commercial vineyards in Napa County, California. Vineyard K1 (1.1 ha in area) was planted in spring 1997 with dormant benchgrafts of $V$. vinifera cv. Cabernet Sauvignon (clone 337) on 110R rootstock $(V$. berlandieri Planch. $\times V$. rupestris Scheele). Vineyard N1 (2.6 ha in area) was planted in spring 1996 with dormant benchgrafts of Cabernet Sauvignon (clone 4) on $110 \mathrm{R}$ rootstock. Vine spacing in both vineyards was $1.8 \mathrm{~m}$ within rows and 2.3 $\mathrm{m}$ between rows (east-to-west row orientation), and grapevines were unilateral-cordon trained to a vertical shoot-positioning system. Both vineyards were drip irrigated for most of the growing season (13.2 liters per vine, approximately twice per week from May to October) with two drip emitters per grapevine positioned $0.25 \mathrm{~m}$ from one side of each grapevine trunk and 0.75 $\mathrm{m}$ from the opposite side of the trunk. Both vineyards were established on land previously occupied by scattered oak woodlands.

In July 2002, 6 weeks after budbreak, all grapevines in both vineyards $(2,220$ in vineyard K1 and 4,870 in vineyard N1) were categorized as symptomless, moderately symptomatic, or severely symptomatic based on approximate shoot length. Shoot length was measured relative to the three pairs of horizontal trellis system catch wires positioned at fixed intervals above the grapevine cordons. Grapevines with the most shoots extending to or above the high catch wires (shoot length $\geq 1 \mathrm{~m}$ ) were categorized as healthy. Grapevines with most shoots extending between the high and the low catch wires (shoot length 0.3 to $1 \mathrm{~m}$ ) were categorized as moderately symptomatic. Grapevines with no shoots extending past the low catch wires (shoot length $\leq 0.3 \mathrm{~m}$ ) were categorized as severely symptomatic.

To verify the presence of $A$. mellea root collar infection on moderately symptomatic grapevines, a shovel was used to clear soil from the base of their root collars (to a soil depth of approximately $0.3 \mathrm{~m}$ ) and a small piece of bark (approximately 2 $\mathrm{cm}^{2}$ in area) was removed from the base of the trunk and from each main root to expose mycelial fans. Among all moderately symptomatic grapevines confirmed infected, 100 were randomly selected per vineyard. Severely symptomatic grape- vines were not selected because a preliminary study on root collar excavation in 2000 and 2001 at the same vineyards showed that grapevines with severe symptoms in July often died before harvest (data not shown).

Among all symptomless grapevines, 100 were randomly selected per vineyard for inclusion in the study, and their root collars were examined to verify the absence of $A$. mellea. In an effort to avoid sampling symptomless grapevines that were infected on deeper parts of their root systems, grapevines immediately adjacent to a dead grapevine or a severely symptomatic grapevine were excluded. Hereafter, symptomless grapevines with no mycelial fans at their root collars will be referred to as "healthy", with the understanding that some might actually have been infected, but were not yet symptomatic. Moderately symptomatic grapevines with mycelial fans at their root collars will be referred to as "symptomatic".

In August 2002, a shovel was used to remove soil (approximately $0.5 \mathrm{~m}$ in diameter by $0.3 \mathrm{~m}$ in depth) to expose the root collars of 50 healthy grapevines and 50 symptomatic grapevines per vineyard. Root collar excavation exposed the base of the trunk, to the depth at which main roots were present (approximately $30 \mathrm{~cm}$ deep), and a portion of the main roots (the section of approximately $10 \mathrm{~cm}$ of main roots where they originated from the base of the trunk). The remaining 50 healthy grapevines and 50 symptomatic grapevines per vineyard served as nonexcavated controls, giving a total of four experimental treatments: healthy-excavated, healthy-nonexcavated, symptomatic-excavated, and symptomatic-nonexcavated. Soil movement caused by heavy rains or gopher activity necessitated re-excavation of some root collars, which was undertaken at approximately 2-month intervals throughout the experiment.

In October 2002 and 2003, 30 grapevines per treatment per vineyard were randomly selected and assessed for yield data. On the day of harvest, clusters of fruit were counted, harvested, and weighed from a total of 120 grapevines per vineyard. Average cluster weight was obtained by dividing yield by cluster number, giving three standard grapevine yield parameters: cluster number, yield (kg/vine), and cluster weight (g). In March 2004, dormant prunings from the same grapevines from which yield data was collected were conventionally pruned to 5-cm-long spurs and the prunings were weighed. Average shoot weight was obtained by dividing pruning weight by shoot number, resulting in a total of three standard grapevine growth parameters: shoot number, pruning weight (kg/vine), and shoot weight (g).

Root collars were reexamined in March 2004 to determine if root collar excavation caused mycelial fans, that were present on symptomatic grapevines prior to excavation, to recede. Healthy grapevines were reexamined to ensure that mycelial fans were still absent from their root collars. For excavated grapevines, a small piece of bark (approximately $2 \mathrm{~cm}^{2}$ in area) was removed from the base of the trunk and from each main root that was exposed by root collar excavation. Main roots on excavated grapevines were examined approximately $20 \mathrm{~cm}$ below the soil line of the excavated root collar. For nonexcavated grapevines, a shovel was used to clear soil from the base of their root collars (to a soil depth of approximately $0.3 \mathrm{~m}$ ) and a small piece of bark was removed to look for mycelial fans. Healthy grapevines did not appear to have foliar symptoms of Armillaria root disease, but were reexamined for the sake of thoroughness.

Data were analyzed using the MIXED procedure in SAS (SAS System, version 8.2; SAS Institute Inc., Cary, NC) with Kenward-Roger as the denominator degrees of freedom method. Experiments in the vineyards were treated as two completely randomized designs. A three-way analysis of variance (ANOVA) was used to determine the effects of year (2002 or 2003), vine status (healthy or symptomatic), root collar excavation (excavated or nonexcavated), and their interactions, all of which were considered fixed effects, on yield parameters. Year was treated as a repeated measure. A two-way ANOVA was used to determine the effects of vine status, root collar excavation, and their interactions on growth parameters. A square root transformation was applied to pruning weights from vineyard $\mathrm{K} 1$ and a $\log _{10}$ transformation to shoot weights from vineyard $\mathrm{K} 1$ to normalize variances (reversetransformed treatment means and 95\% confidence intervals are presented in figures). Tukey's tests were used for treatment mean comparisons.

Separation of data sets from the two vineyards was required because, in vineyard $\mathrm{K} 1$ much more so than in vineyard $\mathrm{N} 1$, excavated root collars were frequently refilled with soil. The objective of this experiment was to examine the efficacy of root collar excavation for control of Armillaria root disease; therefore, it was important to acknowledge that the treatment was potentially compromised in vineyard K1.

\section{RESULTS}

Root collar excavation. Although excavated root collars were routinely cleared approximately every 2 months, they occasionally became refilled. Most refilling was due to gopher activity, as evidenced by the presence of gopher mounds in refilled root collar excavations, but some was due to heavy winter rains that eroded soil from high points of the vineyards and deposited it into excavated root collars of grapevines at the bottom of slopes. Excavated root collars were refilled more frequently in 
vineyard K1 than in vineyard N1. For example, among the 30 symptomaticexcavated grapevines in vineyard $\mathrm{K} 1$ from which yield data were collected in 2003, 15 were found to be completely full of soil 2 weeks before harvest. On the same date, only four symptomatic-excavated grapevines had been refilled in vineyard N1.

After reexamining root collars in March 2004, mycelial fans were found on all symptomatic-nonexcavated grapevines in both vineyards at a soil depth of approximately 10 to $20 \mathrm{~cm}$. On symptomaticexcavated grapevines in both vineyards, mycelial fans were absent from the base of the trunk and sections of main roots exposed by root collar excavation. Mycelial fans were present on sections of main roots distal to exposed sections (i.e., sections of main roots that were not exposed by root collar excavation) on symptomaticexcavated grapevines. Mycelial fans were absent from the root collars of healthy grapevines, both excavated and nonexcavated, in both vineyards.

Effects of year. More clusters were removed (thinned) postveraison in both vineyards in 2003 due to winery demands for higher juice quality. Cluster thinning was so severe in vineyard $\mathrm{K} 1$ that it resulted in significant yield losses for healthy and symptomatic grapevines (data not shown). Results were similar for cluster number in vineyard N1, where heavier cluster thinning resulted in lower cluster number for healthy and symptomatic grapevines in 2003 and lower cluster number for excavated and nonexcavated grapevines in 2003 (data not shown). Because there were no significant year $\times$ vine status $\times$ excavation interactions in either vineyard (Table 1), 2002 and 2003 yield parameters were averaged across years and presented in Figure 1.

Vineyard K1. Healthy grapevines in vineyard K1 had significantly higher cluster number, higher yield, and higher cluster weight than symptomatic grapevines (data not shown). Despite the significant vine status $\times$ excavation interaction effect on cluster number and yield (Table 1), differences between excavated and nonex-
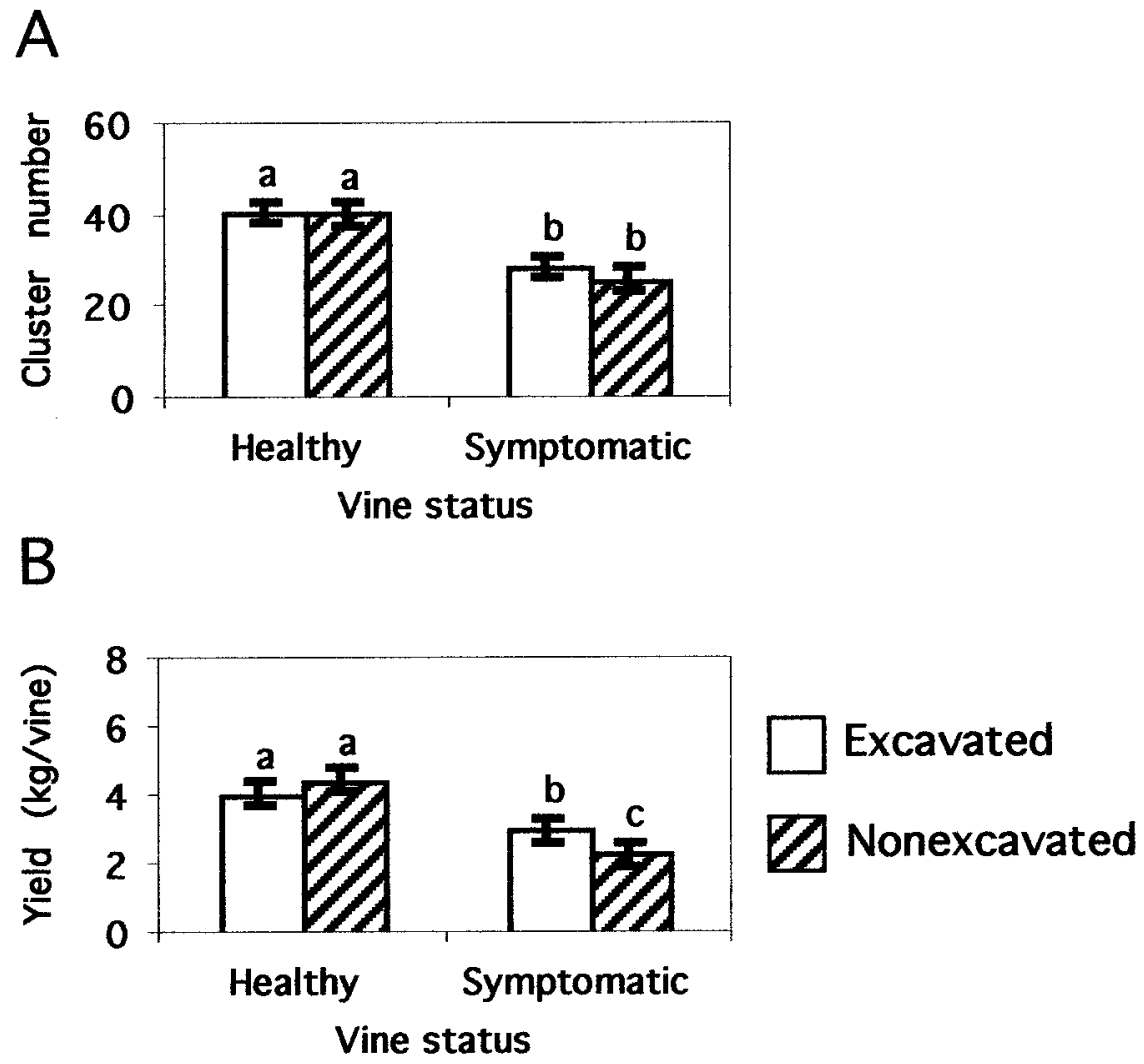

C

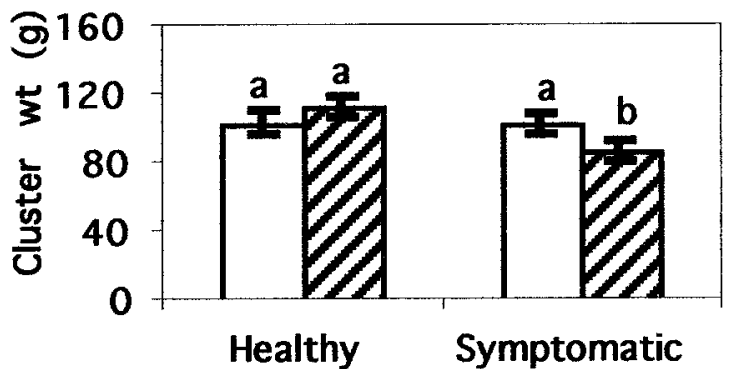

Vine status

Fig. 1. Effects of root collar excavation on $\mathbf{A}$, cluster number, B, yield, and $\mathbf{C}$, cluster weight of healthy and symptomatic grapevines in vineyard N1. Error bars represent $95 \%$ confidence limits. Each column is the mean of 60 observations summed over 2002 and 2003 harvests. Columns with different letters are significant at $P \leq 0.05$, Tukey's test.

Table 1. $F$ values from analyses of variance for combined 2002 and 2003 cluster number, yield, and cluster weight of healthy and symptomatic grapevines, with or without root collar excavation, in vineyards K1 and N1

\begin{tabular}{|c|c|c|c|c|c|c|}
\hline \multirow[b]{3}{*}{ Source $^{b}$} & \multicolumn{6}{|c|}{$F$ values $^{\text {a }}$} \\
\hline & \multicolumn{3}{|c|}{ Vineyard K1 } & \multicolumn{3}{|c|}{ Vineyard N1 } \\
\hline & Cluster number & Yield & Cluster weight & Cluster number & Yield & Cluster weight \\
\hline Year & $206.40 * *$ & $60.40 * *$ & $15.01 * *$ & $58.99 * *$ & 2.00 & $125.67 * *$ \\
\hline Status & $142.68 * *$ & $188.12 * *$ & $69.97 * *$ & $112.53 * *$ & $82.68 * *$ & $16.92 * *$ \\
\hline Year $\times$ status & 2.85 & $4.29^{*}$ & 0.01 & $4.16^{*}$ & 0.04 & 0.70 \\
\hline Excavation & 0.15 & 0.03 & 0.13 & 1.50 & 0.79 & 0.93 \\
\hline Year $\times$ excavation & 0.51 & 0.15 & 1.55 & $5.82 *$ & 3.84 & 0.34 \\
\hline Status $\times$ excavation & $4.63^{*}$ & $5.39 *$ & 1.18 & 0.94 & $10.07 *$ & $14.87 * *$ \\
\hline Year $\times$ status $\times$ excavation & 3.55 & 2.59 & 0.33 & 0.94 & 0.19 & 0.22 \\
\hline
\end{tabular}

${ }^{a}$ Denominator degrees of freedom are 232 for all main and interaction effects (Kenward-Roger denominator degrees of freedom method); * and $* *$ indicate significance at $P \leq 0.05$ and 0.0001 , respectively.

${ }^{\mathrm{b}}$ Source of variation: October 2002 or October 2003 (year), healthy or symptomatic grapevine (status), excavated or nonexcavated root collar (excavation). 
cavated grapevines in both vine status categories were not significant after mean comparisons with Tukey's test (data not shown).

Shoot number, pruning weight, and shoot weight of healthy grapevines in vineyard K1 were significantly higher than those of symptomatic grapevines (Table 2; Fig. 2A-C). Pruning weight and shoot weight of healthy-excavated grapevines were significantly lower than those of healthy-nonexcavated grapevines (Fig. 2B and C). Excavation had no statistically significant effect on growth parameters of symptomatic grapevines (Fig. 2A-C).

Vineyard N1. Healthy grapevines in vineyard N1 had significantly higher cluster number and higher yield than sympto-

Table 2. $F$ values from analyses of variance for 2003 shoot number, pruning weight, and shoot weight of healthy and symptomatic grapevines, with or without root collar excavation in vineyards K1 and N1

\begin{tabular}{|c|c|c|c|c|c|c|}
\hline \multirow[b]{3}{*}{ Source $^{b}$} & \multicolumn{6}{|c|}{$F$ values $^{\mathbf{a}}$} \\
\hline & \multicolumn{3}{|c|}{ Vineyard K1 } & \multicolumn{3}{|c|}{ Vineyard N1 } \\
\hline & Shoot number & Pruning weight & Shoot weight & Shoot number & Pruning weight & Shoot weight \\
\hline Status & $55.17 * *$ & $88.99 * *$ & $51.76^{* *}$ & $27.88 * *$ & $24.31 * *$ & $17.55^{* *}$ \\
\hline Excavation & 0.01 & 1.88 & 0.30 & 0.11 & 0.27 & 0.20 \\
\hline Status $\times$ excavation & $4.18^{*}$ & $17.71 * *$ & $10.87 *$ & $9.71 *$ & 3.33 & 1.31 \\
\hline
\end{tabular}

${ }^{a}$ Denominator degrees of freedom are 116 for all main and interaction effects (Kenward-Roger denominator degrees of freedom method); * and $* *$ indicate significance at $P \leq 0.05$ and 0.0001 , respectively.

${ }^{\mathrm{b}}$ Source of variation: healthy or symptomatic grapevine (status), excavated or nonexcavated root collar (excavation).

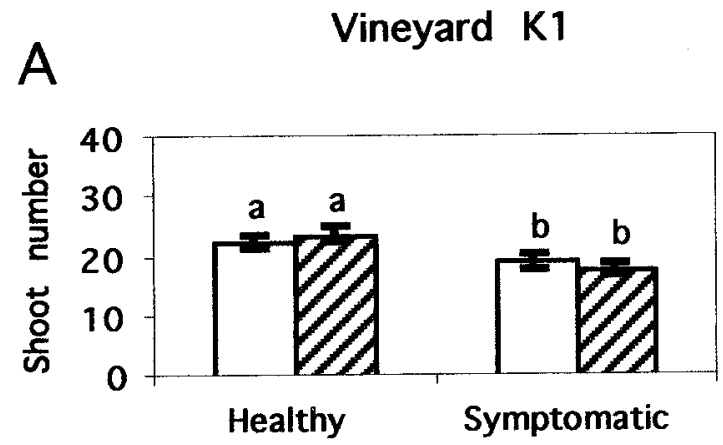

B

\section{Vine status}
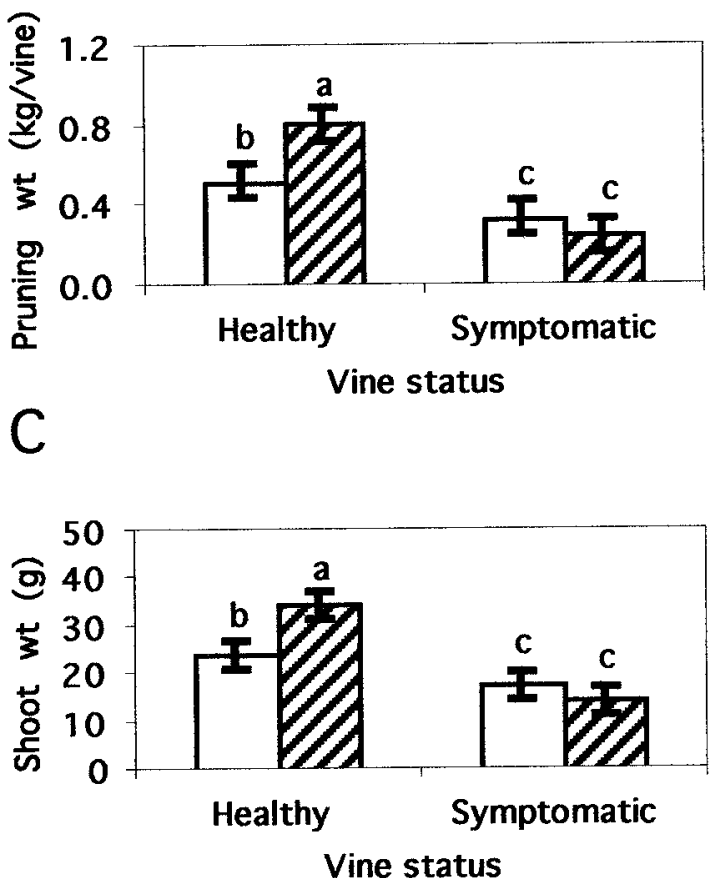

Vine status
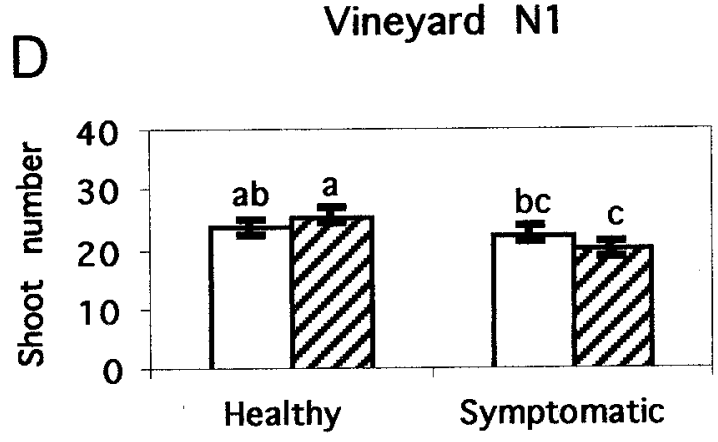

E

Vine status
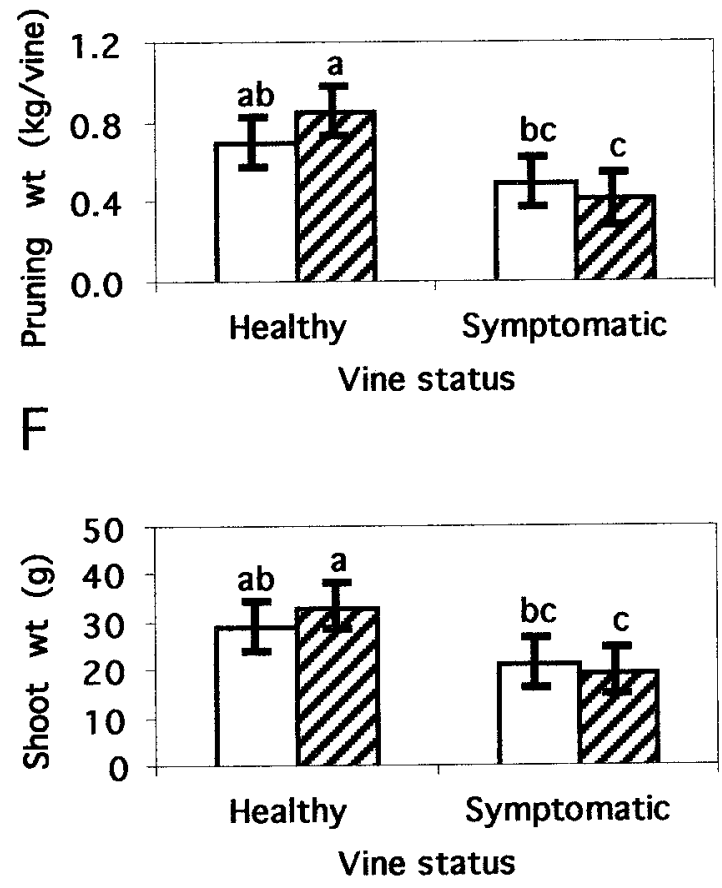

Nonexcavated

Fig. 2. Effects of root collar excavation on shoot number, pruning weight, and shoot weight of healthy and symptomatic grapevines in two California vineyards. Error bars represent $95 \%$ confidence limits. Each column is the mean of 30 observations. Columns with different letters are significant at $P \leq 0.05$, Tukey's test. A, B, and $\mathbf{C}$, vineyard K1; D, E, and F, vineyard N1. 
matic grapevines (Fig. 1A and B). Excavation significantly improved yield and cluster weight of symptomatic grapevines in vineyard N1 (Table 1; Fig. 1B and C). Cluster weight of symptomatic-excavated grapevines was as high as that of healthy grapevines (Fig. 1C).

Shoot number of symptomatic-excavated grapevines was intermediate between that of healthy-excavated grapevines and symptomatic-nonexcavated grapevines (Fig. 2D). Although pruning weight and shoot weight of symptomatic-excavated grapevines also were intermediate between that of healthy-excavated grapevines and symptomatic-nonexcavated grapevines, ANOVA did not detect a significant vine status $\times$ excavation interaction for pruning weight or shoot weight (Table 2).

\section{DISCUSSION}

Based on analyses of yield parameters, root collar excavation had positive effects on symptomatic grapevines in one of the two examined vineyards. There were encouraging results in vineyard N1: (i) symptomatic-excavated grapevines had significantly higher yield than symptomaticnonexcavated grapevines and (ii) symptomatic-excavated grapevines maintained the same high cluster weight as healthy grapevines. In vineyard $\mathrm{K} 1$, root collar excavation had no statistically significant effects on mean yield parameters of symptomatic grapevines.

Symptomatic grapevines in both vineyards had significantly less growth and yield than healthy grapevines, as demonstrated by significant differences in growth and yield parameters in vineyard $\mathrm{K} 1$, and in yield in vineyard N1. These results demonstrate that the presence of a mycelial fan at the root collar and moderately stunted shoot growth are associated with lower growth and yield parameters in symptomatic grapevines. Therefore, it appears that using growth and yield data to evaluate the efficacy of root collar excavation for postinfection control of Armillaria root disease is justified. This disease assessment approach may be useful for other studies involving control of Armillaria root disease on grapevine.

Differences in success of root collar excavation in the examined vineyards may be due to frequent refilling of excavated root collars in vineyard K1. However, mycelial fans receded from the base of the trunk and sections of main roots exposed by root collar excavation on symptomatic-excavated grapevines in both vineyards. Frequent refilling of excavated root collars in vineyard K1 may have caused mycelial fans to recede at a slower rate than occurred in vineyard N1, but it is not possible to evaluate this without root collar examinations earlier in the experiment. Differences in success of root collar excavation instead may be due to differences in extent of infection among symptomatic grape- vines. Symptomatic grapevines in vineyard K1 may have had a higher proportion of mycelial fans covering sections of main roots distal to sections exposed by root collar excavation, such that recession of a mycelial fan from the root collar was not sufficient to prevent A. mellea girdling of main roots.

Root collar excavation affects mycelial fans present at the root collar, but the mechanism by which this occurs is not known. Host responses to A. mellea infection may inhibit mycelial fan growth. Grapevine roots exhibit host responses to A. mellea infection that are typical of other tolerant host species $(17,20)$, including formation of a gummy deposit in xylem vessels surrounding hyphae, cork and callus formation beneath small mycelial fans, and adventitious root formation arising from callus tissue (K. Baumgartner, unpublished). Exposure of the root collar to higher temperatures or drying, both of which have been shown to kill or inhibit $A$. mellea in infected wood (11), may inhibit mycelial fan growth. Grapevine trunk and root bark is extremely thin (approximately $1 \mathrm{~mm}$ ), which makes grapevine wood subject to drying, as evidenced by the need to mound soil or place plastic growth tubes around newly planted, dormant benchgrafts (6).

Root collar excavation apparently harmed healthy grapevines in vineyard $\mathrm{K} 1$, as evidenced by significantly lower pruning weight and shoot weight. Decreased growth of healthy-excavated grapevines may be due to evaporation of moisture through exposed root collar bark, a situation that, as stated above, may help symptomatic grapevines. Another possible explanation for decreased growth is removal of fine roots from healthy-excavated grapevines during root collar excavation and, thus, decreased capacity for uptake of water and soil-derived nutrients. Grapevine fine roots often are concentrated at the base of the trunk in the upper $0.45 \mathrm{~m}$ of soil (8). If removal of fine roots decreased growth of healthy-excavated grapevines, this does not explain why symptomaticexcavated grapevines had higher yield. However, fine roots may not have been concentrated at the root collars of symptomatic-excavated grapevines, due to the presence of mycelial fans.

Root collar excavation did not eradicate A. mellea from symptomatic grapevines and, therefore, may not provide long-term control of root disease on grapevines that showed yield increases. Mycelial fans receded from excavated root collars, but distal main root infections persisted. However, root collar excavation may extend the productive life of symptomatic grapevines, as has been shown in Citrus spp. $(5,11)$, thereby potentially improving yields for a few years before grapevines die and need to be replanted. Focusing control efforts on infected grapevines that still produce nor- mal clusters is a cost-effective strategy, given that replants are not immediately productive and often are infected eventually by $A$. mellea (4). Root collar excavation is neither reliant on fungicides, nor does it require expensive equipment. Labor costs, which may be partially offset by increased yields, could be lowered by adopting the use of a sturdy insert that prevents refilling of excavated root collars.

Based on this study's findings of yield and cluster weight increases among symptomatic-excavated grapevines, coupled with the results of past research that demonstrated that root collar excavation extended the productive life of infected Citrus spp. $(5,11)$, it appears that root collar excavation may be promising for postinfection control of Armillaria root disease of grapevine. Unfortunately, it is difficult to make inferences about the success of root collar excavation in all diseased vineyards based on significant yield improvements among symptomatic grapevines at one of two vineyards examined in this study. Additional testing of root collar excavation is required to accommodate the wide variety of grapevine rootstocks, soil types, and irrigation practices used in California grape-growing regions.

\section{ACKNOWLEDGMENTS}

I thank J. Krupp for use of field sites; J. Warren and S. Schnabel for field assistance; and D. Rizzo (Department of Plant Pathology, University of California, Davis), T. Gordon (Department of Plant Pathology, University of California, Davis), G. Browne (United States Department of AgricultureAgricultural Research Service [USDA-ARS], Davis, CA), and P. Cousins (USDA-ARS, Geneva, $\mathrm{NY}$ ) for their valuable comments on this manuscript.

\section{LITERATURE CITED}

1. Adaskaveg, J. E., Forster, H., Wade, L., Thompson, D. F., and Connell, J. H. 1999. Efficacy of sodium tetrathiocarbonate and propiconazole in managing Armillaria root rot of almond on peach rootstock. Plant Dis. 83:240246.

2. Baumgartner, K., and Rizzo, D. M. 2001. Distribution of Armillaria species in California. Mycologia 93:821-830.

3. Baumgartner, K., and Rizzo, D. M. 2001. Ecology of Armillaria species in mixed-hardwood forests of California. Plant Dis. 85:947 951.

4. Baumgartner, K., and Rizzo, D. M. 2002. Spread of Armillaria Root Disease in a California vineyard. Am. J. Enol. Vitic. 53:197203.

5. Bliss, D. E. 1944. Controlling Armillaria root rot in citrus. Lithoprint \#50. University of California Agricultural Experiment Station, Berkeley.

6. Boehm, E. W., and Coombe, B. G. 1992 Vineyard Establishment. Pages 23-41 in: Viticulture, Vol. 2-Practices. B. G. Coombe and P. R. Dry, eds. Winetitles, Adelaide, Australia.

7. Jacobs, K. A., MacDonald, J. D., Cobb, F. W., and Wells, K. 1994. Identification of Armillaria species in California. Mycologia 86:113116.

8. Morlat, R., and Jacquet, A. 2003. Grapevine root system and soil characteristics in a vineyard maintained long-term with or without interrow sward. Am. J. Enol. Vitic. 54:1-7. 
9. Munnecke, D. E., Kolbezen, M. J., and Wilbur, W. D. 1973. Effect of methyl bromide or carbon disulfide on Armillaria and Trichoderma growing on agar medium and relation to survival of Armillaria in soil following fumigation. Phytopathology 63:1352-1357.

10. Munnecke, D. E., Kolbezen, M. J., Wilbur, W. D., and Ohr, H. D. 1981. Interactions involved in controlling Armillaria mellea. Plant Dis. 65:384-389.

11. Munnecke, D. E., Wilbur, W., and Darely, E. 1976. Effect of heating or drying on Armillaria mellea and Trichoderma viride and the relation to survival of $A$. mellea in soil. Phytopathology 66:1363-1368.
12. Ohr, H. D., Munnecke, D. E., and Bricker, J. L. 1973. The interaction of Armillaria mellea and Trichoderma spp. as modified by methyl bromide. Phytopathology 63:965-973.

13. Raabe, R. 1988. Armillaria Root Rot. Pages 35-36 in: Compendium of Grape Diseases. R. C. Pearson and A. C. Goheen, eds. American Phytopathological Society, St. Paul, MN.

14. Raabe, R. D. 1966. Testing plants for resistance to oak root fungus. Calif. Agric. 20:12.

15. Raabe, R. D. 1979. Testing grape rootstocks for resistance to the oak root fungus. Calif. Plant Pathol. 46:3-4.

16. Redfern, D. B. 1978. Infection by Armillaria mellea and some factors affecting host resis- tance and the severity of disease. Forestry 51:121-135.

17. Rishbeth, J. 1985. Infection cycle of Armillaria and host response. Eur. J. For. Pathol. 15:332-341.

18. Shaw, C. G., III. 1980. Characteristics of Armillaria mellea on pine root systems in expanding centers of root rot. Northwest Sci. 54:137-145.

19. Singh, P. 1980. Armillaria root rot: Artificial inoculation and development of the disease in greenhouse. Eur. J. For. Pathol. 10:420-431.

20. Thomas, H. E. 1934. Studies on Armillaria mellea (Vahl) Quelet: infection, parasitism and host resistance. J. Agric. Res. 48:187-218. 